\title{
In situ studies of growth and pigmentation of the phaeophycean Nereocystis luetkeana
}

\author{
M. J. Duncan \\ Simon Fraser University; \\ Burnaby, B. C., Canada
}

KURZFASSUNG: In-situ-Untersuchungen über Wachstum und Pigmentierung der Phaeophycee Nereocystis luetkeana. Nereocystis luetkeana erreicht während einer Wachstumsperiode eine Stiellänge von bis zu $25 \mathrm{~m}$, wobei die durchschnittliche Verlängerungsrate $13 \mathrm{~cm} / \mathrm{Tag}$ betragen kann. Sobald die Sporophyten die Wasseroberfläche erreichen, endet das Längenwachstum des Stieles, und es beginnt die Ausbildung des Sorus. Mit Hilfe von Felduntersuchungen sollte die Beziehung zwischen Wachstum und Umweltfaktoren geklärt werden. Pflanzen, die vom Tiefen in das Flache versetzt wurden, wiesen eine geringere maximale Verlängerungsrate und kurze Stiele auf. Allerdings entsprach die Stiellänge von Sporophyten, die am Aufwärtswachsen gehindert wurden, mehr der Stiellänge von Pflanzen in größerer als in geringerer Tiefe. An Umweltfaktoren wurden Salzgehalt, Temperatur, Nitratgehalt des Wassers und Spektralverteilung des Lichtes gemessen. Der letzte Faktor dürfte für das Stielwachstum entscheidend sein, möglicherweise wegen des Quotienten Rot/Dunkelrot, der vom Tiefen bis zur Wasseroberfläche hin abnimmt. Außerdem wurde der Einfluß von kurzfristigen Anderungen des natürlichen Unterwasserlichtes auf die Pigmentkonzentration von $N$. luetkeana untersucht. Wurden Sporophyten von $4 \mathrm{~m}$ Wassertiefe bis nahe unter die Wasseroberfläche gebracht, so nahm der Gehalt an Chlorophyll a und $\mathrm{c}$ ab. Bei Pflanzen, die von $2 \mathrm{~m}$ Wassertiefe nach $4 \mathrm{~m}$ Wassertiefe verbracht wurden, zeigten sich allerdings nur geringfügige Änderungen des Chlorophyllgehaltes. Der Carotinoidgehalt blieb bei diesen Verpflanzungen unbeeinflußt.

\section{INTRODUCTION}

Nereocystis luetkeana (Mrrtens) P. \& R., the giant kelp, grows profusely along the eastern Pacific Ocean rim, from the Aleutian Islands to central California (DRUEHL 1970). One of the more remarkable features of this annual alga is its rapid elongation rate, which can reach an average of $25 \mathrm{~cm}$ per day including stipe and blade (ForEMAN 1970) and can produce stipes as long as 25 metres, depending on the water depth. When $N$. luetkeana reaches the surface, stipe elongation is curtailed and spore production begins. Early ecological studies related growth to habitat, particularly depth and movement (Frye 1930, 1906, Hartge 1928, Hurd 1916, MacMillan 1899). Hurd (1916) believed that light, rather than mechanical stretching in response to waves and currents, is responsible for stipe elongation. She considered that intensity rather than quality is the factor curtailing stipe growth and promoting spore production. 
Nrcholson (1970), in a study of intertidal Nereocystis luetkeana, found that stipe elongation ceased and blade elongation increased when the sporophytes reached the surface. Foreman (1970), in an ecological investigation of subtidal $N$. luetkeana, found that in the deeper water the rate of stipe elongation decreased, but did not stop when the sporophytes reached the surface. Blade elongation also decreased but to a lesser extent. He suggested that light quality and intensity influenced stipe elongation, but did not experiment in this area.

The aim of this preliminary in situ study was to attempt to relate the growth pattern of Nereocystis luetkeana to certain environmental parameters, i.e., salinity, temperature, nutrients and particularly spectral irradiance, by comparing stipe elongation rates of sporophytes transplanted to different depths. The possible physiological effects caused by altered depth and attendant changes in radiation, brought about by rapid upward growth and tidal movement were also examined. Field experiments were conducted to learn if young sporophytes could respond physiologically to shortterm changes in depth by altering their pigment concentrations.

\section{MATERIAL AND METHODS}

\section{Growth studies}

Exploratory dives began in January, 1969, in coastal waters of Vancouver Island and the lower mainland of British Columbia (B. C.), Canada, to locate early sporophytes of Nereocystis luetkeana. It should be noted that sporophytes of the kelps which grow together in these waters cannot be distinguished by their gross morphology when they are less than $2 \mathrm{~cm}$ long. At approximately this size Nereocystis luetkeana may be identified by faint lines of subsequent splitting of the blade and a slight thickening at the top of the stipe where the pneumatocyst forms.

Recognizable sporophytes of Nereocystis luetkeana were found in early March about $75 \mathrm{~m}$ offshore in Departure Bay, B. C. Location and depth are given in Figure 1. Small young plants were collected, using SCUBA, from the deeper part of the bed ( $4 \mathrm{~m}$ below mean low tide), measured and attached by their holdfasts to numbered bricks with rubber bands, and moved to shallower water ( $2 \mathrm{~m}$ below mean low tide). Additional plants of corresponding size were similarly attached to bricks and left at their natural depth as controls. Stipe length, blade length and number of blades were measured at weekly or biweekly intervals from 19 March to $9 \mathrm{May}$, at which time storms destroyed all of the plants. Sporophytes which were lost during the first four weeks were replaced with others of equivalent size.

Another experiment was conducted to compare the growth pattern of plants prevented from reaching the surface with others placed nearer the surface and with sporophytes left at their natural depth as controls. This study was carried our during June and July in a kelp bed in Maynard Cove, B. C. (Fig. 2), a more protected area than Departure Bay. Ten sporophytes of Nereacystis luetkeana, with stipes between 30 and $50 \mathrm{~cm}$ long, were placed at three positions. In one situation the specimens were attached to individual bricks by their holdfasts and their pneumatocysts were tied to the bricks or nearby rocks with cod line (smooth cotton cord) thus preventing their 


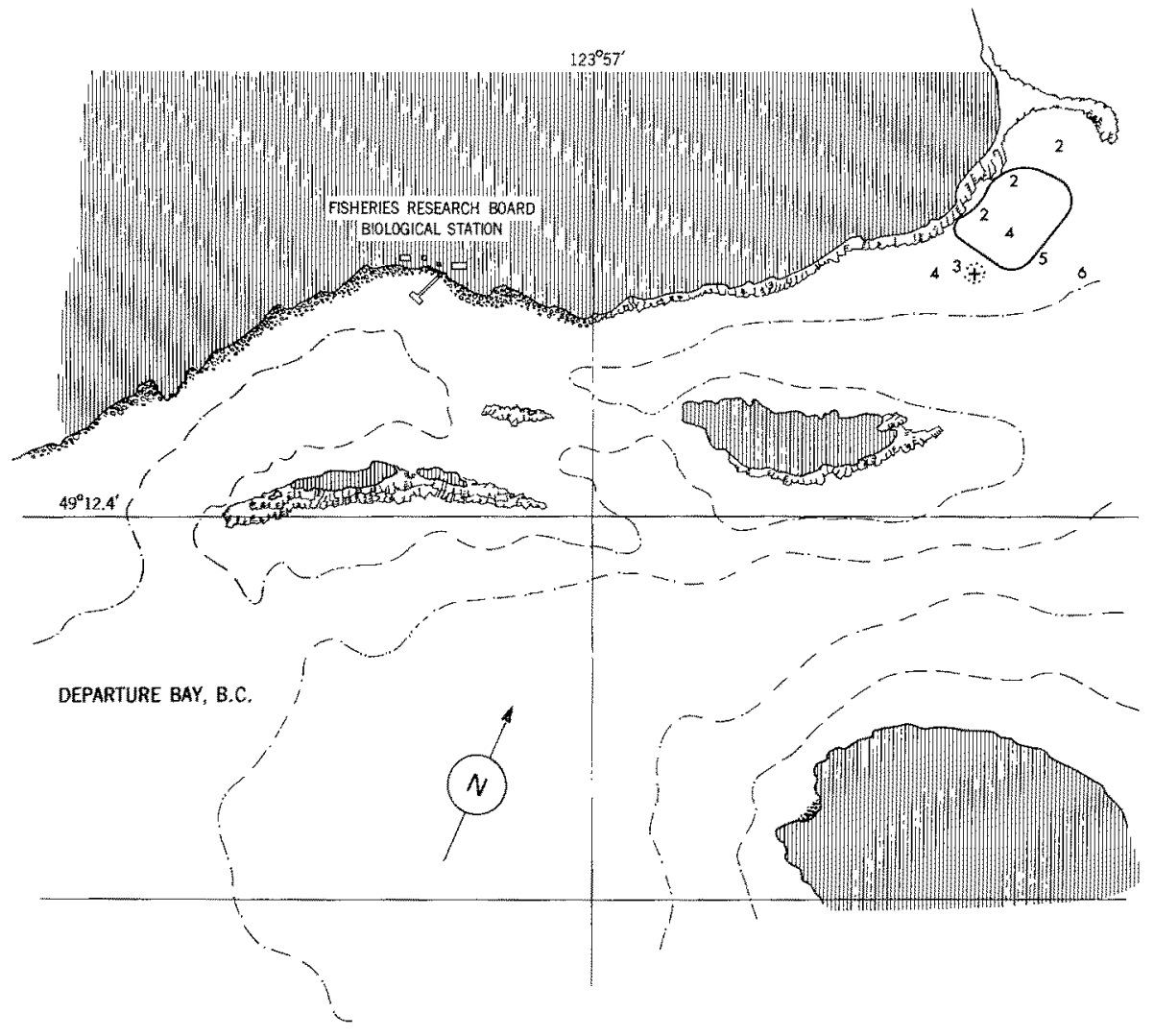

Fig. 1: Site of transplant and pigment studies on Nereocystis luetkeana, at Departure Bay, B. C., in encircled area east of Fisheries Research Board Biological Station. Figures are depth in metres below mean low tide. (After Canadian Hydrographic Service Chart, No. 3509)

reaching the surface. The second group was placed one metre closer to the surface by tying each holdfast to one end of a $1 \mathrm{~m}$ length of cod line, the other end of which was tied to a brick placed on the bottom. The remaining ten specimens were left at their natural depth as controls. The depth was $4.5 \mathrm{~m}$ below mean low tide. All sporophytes were measured after four weeks, by which time spore production had started.

\section{Pigment studies}

These experiments were conducted at Departure Bay, B. C., in the kelp bed shown in Figure 1. Small juvenile plants of approximately the same size were collected from the deep $(4 \mathrm{~m})$ and shallow $(2 \mathrm{~m})$ regions of the kelp bed and attached by their stipes with alligator clips at $45 \mathrm{~cm}$ and $4 \mathrm{~m}$ from the surface to lines which were suspended from a pipe supported by two floats. The lines were weighted to keep them vertical. The whole apparatus was anchored to the bottom and attached by a line to the boat. 


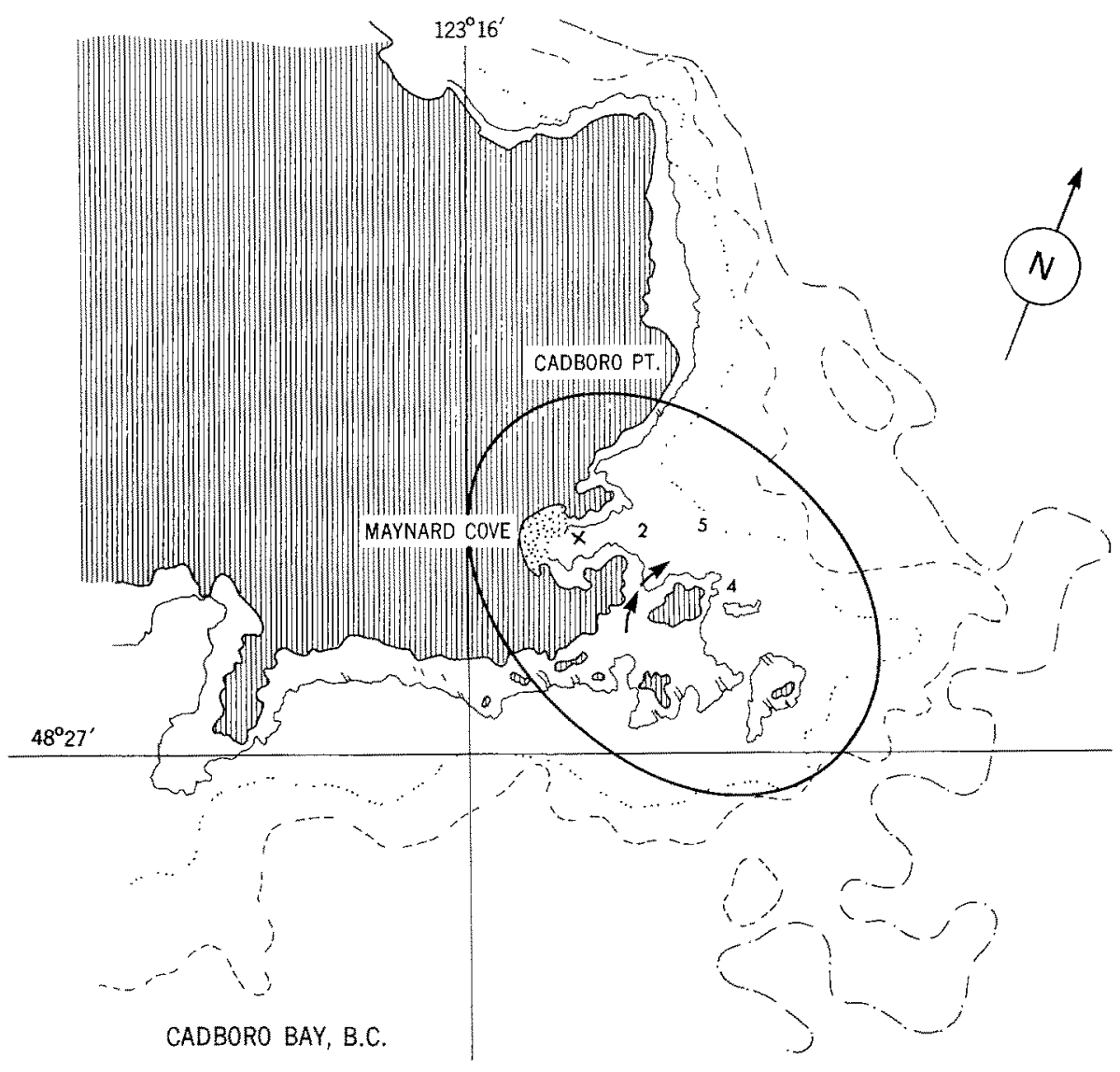

Fig. 2: Site of Nereocystis luetkeana transplant study at Maynard Cove, Cadboro Bay, B. C. The $\mathrm{X}$ within the circle marks the area of the study, $4.5 \mathrm{~m}$ below mean low tide. The arrows mark region of a rapid current across a reef at the mouth of the cove, and the figures are the depths, in metres of adjacent waters

The algae were left at their respective positions for four hours, at which time a diver covered them with aluminum foil and brought them to the boat, where they were wrapped in damp towelling, iced and transported to the laboratory for pigment analysis. Pigments were also analyzed from additional plants collected at the end of the four hours from deep $(4 \mathrm{~m})$ and shallow $(2 \mathrm{~m})$ water as controls. Five such experiments were performed beginning in March and ending in June, 1970. Pigments from the first $2 \mathrm{~cm}$ of the meristematic region of blade tissue were extracted and analyzed according to the method of SEELY et al. (1972).

\section{Measurement of environmental parameters}

Salinity and temperature were measured with an induction salinometer at the surface and at different levels in the kelp bed at Departure Bay. Measurements were 
taken frequently during the rapid growth period of Nereocystis luetkeana (March to May) and at irregular intervals thereafter during 1969 and 1970. Water samples were collected in polyethylene bottles and immediately frozen in dry ice for subsequent nitrate analysis (WOOD et al. 1967). Spectral irradiance, at various depths and on deck was measured at 17 wavelengths from $400 \mathrm{~nm}$ to $729 \mathrm{~nm}$, with a submersible portable spectroradiometer designed for the purpose (Burr \& Duncan 1972). A diver assisted in positioning the underwater instruments, and readings were taken on board an outboard motor boat, kindly loaned by the Fisheries Research Board of Canada Biological Station, Nanaimo, B. C.

\section{RESULTS}

Average stipe elongation rates of the control specimens of Nereocystis luetkeana at $4 \mathrm{~m}$ (below mean low tide) and the transplanted specimens at $2 \mathrm{~m}$ (below mean low tide) are given in Table 1. At the end of the experiment the control specimens had longer stipes than the transplants, and a significantly greater average maximum rate of stipe elongation, i.e. $7.8 \mathrm{~cm}$ per day compared with $5.0 \mathrm{~cm}$ per day $(P<0.02)$. The control plants all reached their maximum elongation rate in the week ending May 1. The time of maximum elongation of stipes of the transplants was not so clearly defined, as few survived to the final day of measurement. The fastest rate of stipe elongation was $12 \mathrm{~cm}$ per day, measured for one control plant.

Table 1

Average stipe elongation rates of Nereocystis luetkeana sporophytes for last four weeks of transplants from $4 \mathrm{~m}$ to $2 \mathrm{~m}$, and last three weeks of control plants left at $4 \mathrm{~m}$ below mean low tide level

\begin{tabular}{|c|c|c|c|c|c|c|}
\hline $\begin{array}{l}\text { Transplants } \\
\text { and } \\
\text { controls }\end{array}$ & $\begin{array}{r}\text { Me } \\
\text { April } 16\end{array}$ & $\begin{array}{l}\text { stipe el } \\
(\mathrm{cm} / \\
\text { April } 23\end{array}$ & $\begin{array}{l}\text { longation } \\
\text { /day) } \\
\text { May } 1\end{array}$ & May 9 & $\begin{array}{l}\text { Mean final } \\
\text { stipe length } \\
(\mathrm{cm})\end{array}$ & $\begin{array}{l}\text { Range } \\
(\mathrm{cm})\end{array}$ \\
\hline $\begin{array}{l}\text { Transplants } \\
\text { Standard error } \\
\text { No. of plants }\end{array}$ & $\begin{array}{c}1.45 \\
\pm 0.51 \\
10\end{array}$ & $\begin{array}{l}2.66 \\
\pm \begin{array}{l}0.72 \\
8\end{array}\end{array}$ & $\begin{array}{l}2.62 \\
\pm 0.84 \\
5\end{array}$ & $\frac{1.38}{3}$ & 73.60 & $35.00-141.00$ \\
\hline $\begin{array}{l}\text { Controls } \\
\text { Standard error } \\
\text { No. of plants }\end{array}$ & & $\begin{array}{c}2.69 \\
+\quad 0.30 \\
10\end{array}$ & $\begin{array}{r}7.79 \\
+1.10 \\
10\end{array}$ & $\frac{3.47}{3}$ & 118.60 & $67.50-178.00$ \\
\hline
\end{tabular}

The results of the study at Maynard Cove are given in Table 2. Sporophytes of Nereocystis luetkeana placed $1 \mathrm{~m}$ closer to the surface $(3.5 \mathrm{~m}$ below mean low tide) had the shortest stipes and the greatest proportion of soral production. The control plants, at their natural growth depth of $4.5 \mathrm{~m}$ below mean low tide had the longest stipes, and the three longest specimens had sori. The four tied-down sporophytes which survived produced no sori, and their average stipe length was intermediate, although closer to the average stipe length of those placed $1 \mathrm{~m}$ nearer the surface. There was a significant difference between the increase in stipe length of the control plants and of 
those nearer the surface $(P<0.01)$ but not between the increase in stipe length of the tied-down plants compared with either those of the controls or the sporophytes nearer the surface.

Table 2

Effects of depth on stipe elongation and soral production of Nereocystis luetkeana over a thirty-day period from June 12 to July 12, 1970, at Maynard Cove, B. C. (A) Plants $1 \mathrm{~m}$ nearer surface ( $3.5 \mathrm{~m}$ below mean low tide); (B) Plants attached to bottom ( $4.5 \mathrm{~m}$ below mean low tide); (C) Control plants - left at natural depth ( $4.5 \mathrm{~m}$ below mean low tide). The ten plants at ead position had initial stipe lengths between 30 and $50 \mathrm{~cm}$

\begin{tabular}{|ccccc|}
\hline Series & $\begin{array}{c}\text { Final } \\
\text { no. of } \\
\text { plants }\end{array}$ & $\begin{array}{c}\text { Mean final } \\
\text { stipe length } \\
(\mathrm{cm})\end{array}$ & $\begin{array}{c}\text { Standard } \\
\text { error }\end{array}$ & $\begin{array}{c}\text { No. of plants } \\
\text { with sori }\end{array}$ \\
\hline (A) & 10 & 170.10 & \pm 10.56 & 6 \\
(B) & 4 & 193.20 & \pm 38.85 & 0 \\
(C) & 10 & 237.00 & \pm 7.04 & 3 \\
\hline
\end{tabular}

To learn the effect of decreased irradiance on mature sporophytes (i.e. with sori), ten were tagged and stipe lengths were measured over a two week period in August. Five of the ten specimens were then tied to the bottom by their pneumatocysts, and stipe lengths measured again at the end of the third week. Rates of blade elongation were also calculated during the final week by punching holes in the blades, $10 \mathrm{~cm}$ from the point of attachment to the pneumatocyst, and measuring the increase in distance at the end of the week. There was a significant decrease $(P<0.01)$ in elongation rates of both stipes and blades of the plants tied down, compared to their rates the previous weeks (see Table 3).

Table 3

Effect of bottom depth ( $4 \mathrm{~m}$ below mean low tide) on elongation rates ( $\mathrm{cm} /$ week) of stipes and blades of mature Nereocystis luetkeana sporophytes, attached to bottom for one week. Stipe lengths of ten tagged plants were measured for two weeks, at which time five were tied to the bottom. Initial average stipe length was $343.0 \mathrm{~cm}$. Below: Standard error

\begin{tabular}{|c|c|c|c|c|c|}
\hline \multicolumn{2}{|c|}{ Control plants $(10)$} & \multirow{2}{*}{\multicolumn{2}{|c|}{$\begin{array}{c}\text { Control plants }(4)^{*} \\
3 r d \text { week }\end{array}$}} & \multirow{2}{*}{\multicolumn{2}{|c|}{$\begin{array}{c}\text { Plants tied to bottom (5) } \\
\text { 3rd week }\end{array}$}} \\
\hline $\begin{array}{l}\text { 1st week } \\
\text { stipes }\end{array}$ & $\begin{array}{l}\text { 2nd week } \\
\text { stipes }\end{array}$ & & & & \\
\hline $\begin{array}{r}17.20 \\
\pm 1.16\end{array}$ & $\begin{array}{r}17.20 \\
\pm 1.16\end{array}$ & $\begin{array}{r}13.25 \\
\pm 2.56\end{array}$ & $\begin{array}{r}14.30 \\
\pm 0.73\end{array}$ & $\begin{array}{r}9.20 \\
+1.25\end{array}$ & $\begin{array}{r}8.98 \\
\pm 1.25\end{array}$ \\
\hline * One plan & lost. & & & & \\
\hline
\end{tabular}

The results of the field experiments to determine effects of short-term alterations in depth and radiation on pigment concentrations were analyzed according to a threeway analysis of variance in which the main parameters were: (1) prehistory (4 $\mathrm{m}$ or $2 \mathrm{~m}$ natural depth); (2) treatment (plants from both depths placed at $0.5 \mathrm{~m}$ or $4 \mathrm{~m}$ below the surface); (3) time (five testing days between March 26 and June 2, 1970). The average concentrations of pigments in blade meristem at each situation and for each day are given in Table 4. 
Table 4

Average of pigment concentrations ( $\mathrm{mg} / \mathrm{g}$ wet weight) from meristematic tissue of deep $(4 \mathrm{~m})$ and shallow-growing $(2 \mathrm{~m})$ sporophytes of Nereocystis luetkeana, placed $0.5 \mathrm{~m}$ and $4 \mathrm{~m}$ below surface for $4 \mathrm{hrs}$, and collected from natural depths as controls, on each of 5 days of field tests. $\mathrm{D}=$ deep-growing plants $(4 \mathrm{~m})$ and $\mathrm{S}=$ shallow-growing $(2 \mathrm{~m})$ plants. $\mathrm{S} . \mathrm{E} .=$ standard error

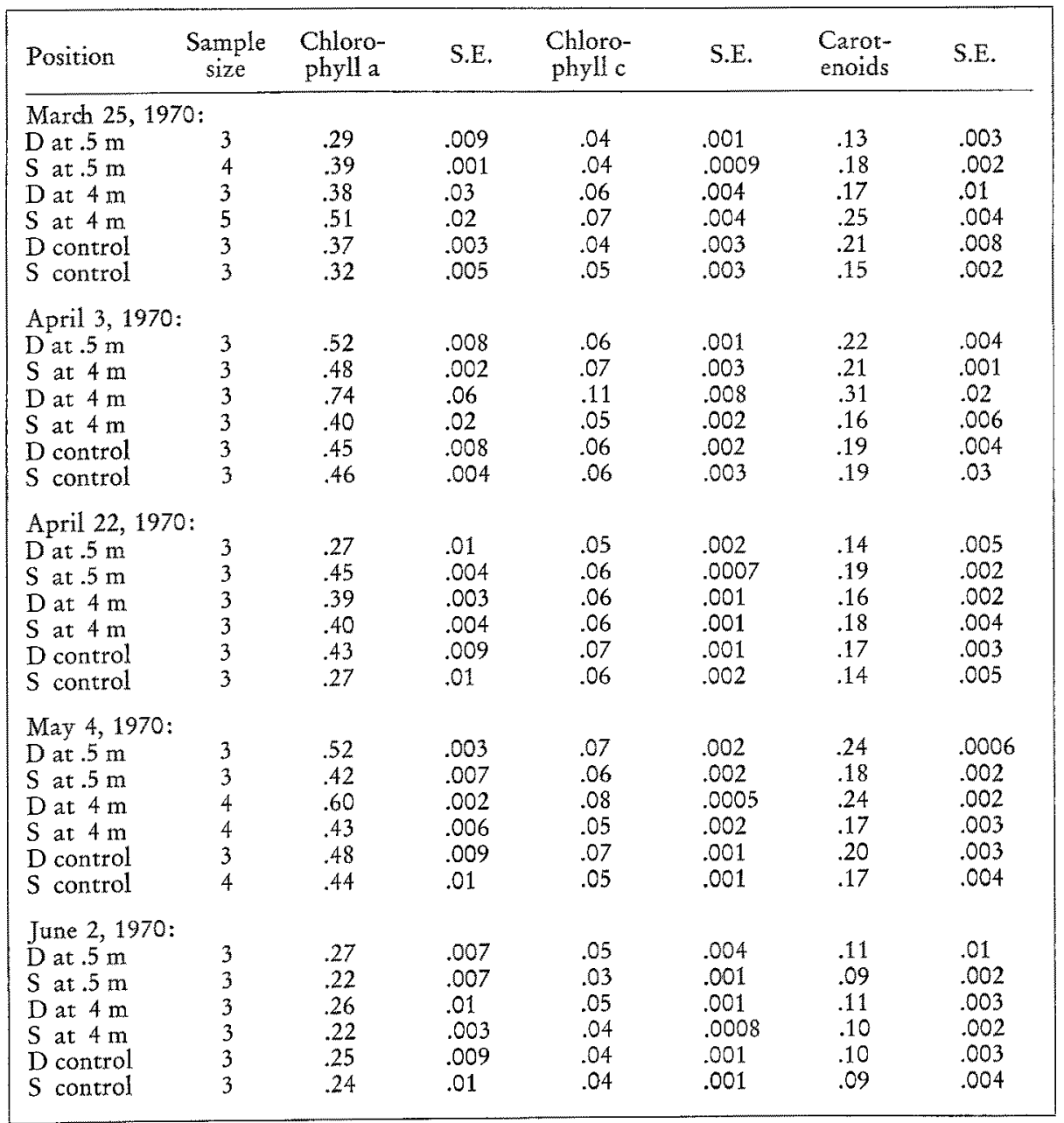

Three-way analysis combining plants under all conditions indicated possible synergism between the three parameters, contributing to differences in pigment concentrations. Further analyses were then made to segregate the factors involved by comparing the components separately. The probabilities of significant differences for all combinations of experimental conditions are presented in Table 5. The depth at which sporophytes of Nereocystis luetkeana grew naturally, either at $4 \mathrm{~m}$ or $2 \mathrm{~m}$ below mean low tide, was the most important factor of those tested to affect pigment concentrations. The treatment of altering depth for four hours resulted in some changes 
in pigments of plants from $4 \mathrm{~m}$ depth, but had no effect on plants from $2 \mathrm{~m}$. Changes in pigment concentrations were evident from day to day, again with greater effects seen in the plants collected from the deeper water. In Table 6 the various treatments are compared between specimens from $4 \mathrm{~m}$ and $2 \mathrm{~m}$ depths.

\section{Table 5}

Three-way analysis of variance comparing experimental depth treatment for four hours on pigments of Nereocystis luetkeana collected from $4 \mathrm{~m}$ and $2 \mathrm{~m}$ below mean low tide, separately and combined, tested on five days from March 26 to June $2,1970 .\left(^{+}=\right.$significant at $\mathrm{P}<0.05 ;^{++}=$significant at $\mathrm{P}<0.01 ; \mathrm{NS}=$ not significant.) Pigment concentrations in plants from $2 \mathrm{~m}$ did not show significant changes. chla $=$ chlorophyll a; chlc $=$ chlorophyll $\mathrm{c}$; car $=$ carotenoids. (A) prehistory (natural depths, $4 \mathrm{~m}$ or $2 \mathrm{~m}$ ); (B) treatment (plants from both depths at $0.5 \mathrm{~m}$ and $4 \mathrm{~m}$ for 4 hours); (C) time ( 5 field tests); c control plants (collected from $4 \mathrm{~m}$ and $2 \mathrm{~m}$, no treatment)

\begin{tabular}{|c|c|c|c|}
\hline & \multicolumn{3}{|c|}{ (A) } \\
\hline (B) & $\begin{array}{l}0.5 \mathrm{~m} \text { vs } \mathrm{c} \text { vs } 4 \mathrm{~m} \\
0.5 \mathrm{~m} \text { vs } 4 \mathrm{~m} \\
0.5 \mathrm{~m} \text { vs } \mathrm{c} \\
4.0 \mathrm{~m} \text { vs } \mathrm{c}\end{array}$ & $\begin{array}{l}\text { chlc }^{++} \\
\text {chla }^{+} ; \text {chlc }^{++} \\
\text {NS } \\
\text { NS }\end{array}$ & $\begin{array}{l}\text { NS } \\
\text { chlct } \\
\text { NS } \\
\text { NS }\end{array}$ \\
\hline$(\mathrm{B}) \times(\mathrm{C})$ & $\begin{array}{l}0.5 \mathrm{~m} \text { vs } \mathrm{c} \text { vs } 4 \mathrm{~m} \\
0.5 \mathrm{~m} \text { vs } 4 \mathrm{~m} \\
0.5 \mathrm{~m} \text { vs } \mathrm{c} \\
4.0 \mathrm{~m} \text { vs } \mathrm{c}\end{array}$ & $\begin{array}{l}\text { NS } \\
\text { chla/chlc } \\
\text { chla } \\
\text { chla } / \text { car }^{++}\end{array}$ & $\begin{array}{l}\text { chla } / \text { car }^{++} \\
\text {chla/chlc } \\
\text { chla/car } \\
\text { NS chla } / \text { car }^{++} \\
\text {N }\end{array}$ \\
\hline$(\mathrm{A}) \times(\mathrm{B}) \times(\mathrm{C})$ & $\begin{array}{l}0.5 \mathrm{~m} \text { vs } \mathrm{c} \text { vs } 4 \mathrm{~m} \\
0.5 \mathrm{~m} \text { vs } 4 \mathrm{~m} \\
0.5 \mathrm{~m} \text { vs } \mathrm{c} \\
4.0 \mathrm{~m} \text { vs } \mathrm{c}\end{array}$ & $\begin{array}{l}\text { NS } \\
\text { NS } \\
\text { NS } \\
\text { NS }\end{array}$ & $\begin{array}{l}\operatorname{car}^{+} \\
\text {NS } \\
\text { chla } \\
\text { car }^{++} ; \mathrm{car}^{++} ; \text {chla } / \mathrm{car}^{+}\end{array}$ \\
\hline
\end{tabular}

Table 6

Three way analysis of variance comparing Nereocystis luetkeana sporophytes from $4 \mathrm{~m}$ and $2 \mathrm{~m}$ below mean low tide, placed at $0.5 \mathrm{~m}$ and $4 \mathrm{~m}$, for 4 hours during five tests from March 26 to June 2,1970. + significant at $P<0.05 ;++$ significant at $P<0.01$; NS not significant. (A) prehistory (natural depths, $4 \mathrm{~m}$ and $2 \mathrm{~m}$ ); (B) treatment (plants from both depths placed at $0.5 \mathrm{~m}$ and 4.0 for four hours); (C) time (five field tests); $\mathrm{c}$ control plants (collected from $4 \mathrm{~m}$ and $2 \mathrm{~m}$, no treatment)

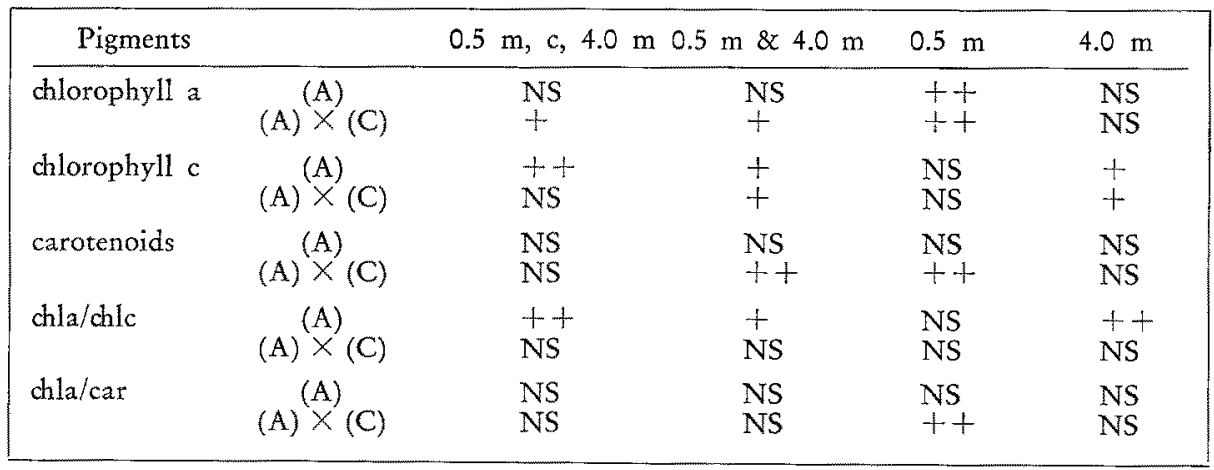


Table 7

Solar radiation at Departure Bay, B. C., on the day preceding (P), the morning preceding $(\mathrm{M})$ and during experiments $(\mathrm{E})$ to test effects of altered depth on pigment concentrations of sporophytes of Nereocystis luetkeana

\begin{tabular}{|c|c|c|c|c|c|}
\hline \multicolumn{3}{|c|}{ Date } & Hours & $\begin{array}{l}\text { Radiance } \\
\text { (lys.) }\end{array}$ & $\begin{array}{l}\text { Daily } \\
\text { total } \\
\text { (lys.) }\end{array}$ \\
\hline $\begin{array}{l}\text { March } \\
\text { March } 2 \\
\text { March } 2\end{array}$ & $\begin{array}{l}25 \\
26 \\
26\end{array}$ & $\begin{array}{l}(\mathrm{P}) \\
(\mathrm{M}) \\
(\mathrm{E})\end{array}$ & $\begin{array}{l}0700-1800 \\
0700-1200 \\
1200-1600\end{array}$ & $\left.\begin{array}{l}263 \\
222\} \\
193\end{array}\right\}$ & $\begin{array}{l}263 \\
415\end{array}$ \\
\hline $\begin{array}{l}\text { April } \\
\text { April } \\
\text { April }\end{array}$ & $\begin{array}{l}2 \\
3 \\
3\end{array}$ & $\begin{array}{l}(\mathrm{P}) \\
(\mathrm{M}) \\
(\mathrm{E})\end{array}$ & $\begin{array}{l}0700-1800 \\
0700-1200 \\
1200-1600\end{array}$ & $\left.\begin{array}{c}492 \\
102 \\
78\end{array}\right\}$ & $\begin{array}{l}492 \\
180\end{array}$ \\
\hline $\begin{array}{ll}\text { April } & 2 \\
\text { April } & 2 \\
\text { April } & 2\end{array}$ & $\begin{array}{l}21 \\
22 \\
22\end{array}$ & $\begin{array}{l}(\mathrm{P}) \\
(\mathrm{M}) \\
(\mathrm{E})\end{array}$ & $\begin{array}{l}0600-1900 \\
0600-1200 \\
1200-1600\end{array}$ & $\left.\begin{array}{l}461 \\
114 \\
147\end{array}\right\}$ & $\begin{array}{l}461 \\
261\end{array}$ \\
\hline $\begin{array}{l}\text { May } \\
\text { May } \\
\text { May }\end{array}$ & $\begin{array}{l}3 \\
4 \\
4\end{array}$ & $\begin{array}{l}(\mathrm{P}) \\
(\mathrm{M}) \\
(\mathrm{E})\end{array}$ & $\begin{array}{l}0600-1900 \\
0600-1200 \\
1200-1600\end{array}$ & $\left.\begin{array}{c}609 \\
881 \\
136\end{array}\right\}$ & $\begin{array}{l}609 \\
224\end{array}$ \\
\hline $\begin{array}{l}\text { June } \\
\text { June } \\
\text { June }\end{array}$ & $\begin{array}{l}1 \\
2 \\
2\end{array}$ & $\begin{array}{l}(\mathrm{P}) \\
(\mathrm{M}) \\
(\mathrm{E})\end{array}$ & $\begin{array}{l}0500-2000 \\
0500-1200 \\
1200-1600\end{array}$ & $\left.\begin{array}{l}704 \\
3611 \\
263\end{array}\right\}$ & $\begin{array}{l}704 \\
624\end{array}$ \\
\hline
\end{tabular}

Chlorophyll a: Concentrations of chlorophyll a were significantly different in the $4 \mathrm{~m}$ sporophytes when placed at $0.5 \mathrm{~m}$ and $4 \mathrm{~m}$ from the surface, the former having the lower concentrations. There was no significant difference in the $2 \mathrm{~m}$ plants. However there was a significant difference in concentrations of chlorophyll a between the $2 \mathrm{~m}$ and $4 \mathrm{~m}$ plants at both depths of the treatment.

Chlorophyll $c$ : Concentrations of chlorophyll $c$ were on the average the same for all the $2 \mathrm{~m}$ plants at either experimetnal position. Plants from $4 \mathrm{~m}$ showed an appreciable difference in concentrations of chlorophyll $\mathrm{c}$ between $0.5 \mathrm{~m}$ and $4 \mathrm{~m}$, the latter being higher. There was no differences in chlorophyll $\mathrm{c}$ concentrations between the $4 \mathrm{~m}$ and $2 \mathrm{~m}$ sporophytes at $0.5 \mathrm{~m}$, but at $4 \mathrm{~m}$ the plants from the deeper water had higher concentrations.

Total carotenoids: The treatment had no effect on carotenoid concentrations of plants from either $4 \mathrm{~m}$ or $2 \mathrm{~m}$ depths. There were, however, differences in carotenoid content between the two, when analyzed over the five days, the deeper-growing plants having the bigher concentration.

On average the ratio of chlorophyll a to chlorophyll $c$ was the same for all shallow plants, and for deep and shallow plants at $45 \mathrm{~cm}$. There was a significant difference between deep and shallow plants at $4 \mathrm{~m}$, with ratios higher for deep plants. The ratio of chlorophyll a to total carotenoids did not change significantly in the deep or shallow plants $(4 \mathrm{~m}$ and $2 \mathrm{~m}$ ) in response to light treatment, but there was a change with time.

The differences in concentrations of all pigments from day to day appear to be caused by the amount of solar radiation on the testing day rather than on the day prior to testing. In Table 7 solar radiation values are given for the time period of the 
Table 8

Salinity and temperature of surface and bottom waters at Departure Bay study site, 1969 and 1970 , and nitrate concentrations measured only in 1969. Salinity and temperature surface data, from Fisheries Research Board (FRB) of Canada Biological Station, Departure Bay, are given for the same days when available. Readings at study site were taken during the early afternoon, and those at the the FRB dock at 0830 approximately

\begin{tabular}{|c|c|c|c|c|c|c|c|c|c|c|}
\hline \multirow[b]{2}{*}{ Date } & & \multicolumn{3}{|c|}{ Salinity $(\% 0)$} & \multicolumn{3}{|c|}{ Temperature $\left({ }^{\circ} \mathrm{C}\right)$} & \multicolumn{3}{|c|}{$\mathrm{NO}_{3}-\mathrm{N} / 1(\mu \mathrm{g} / \mathrm{at})$} \\
\hline & & $\begin{array}{l}\text { sur- } \\
\text { face }\end{array}$ & $\begin{array}{l}\text { bot- } \\
\text { tom }\end{array}$ & FRB & $\begin{array}{l}\text { sur- } \\
\text { face }\end{array}$ & $\begin{array}{l}\text { bot- } \\
\text { tom }\end{array}$ & FRB & $\begin{array}{l}\text { sur- } \\
\text { face }\end{array}$ & $\begin{array}{l}\text { bot- } \\
\text { tom }\end{array}$ & $\begin{array}{l}\text { Bottom } \\
\text { depth }(m)\end{array}$ \\
\hline 1969 & & & & & & & & & & \\
\hline March & 11 & 28.9 & 28.9 & 27.7 & 7.8 & 7.8 & 6.1 & 18.06 & 13.86 & 3.5 \\
\hline April & 5 & 24.9 & 25.6 & 一 & 7.8 & 7.8 & - & 18.90 & 9.66 & 3.5 \\
\hline April & 9 & 26.7 & 27.8 & 25.8 & 8.9 & 8.9 & 8.3 & 9.24 & 9.24 & 5.5 \\
\hline April & 16 & 25.5 & 26.9 & 25.0 & 10.0 & 8.9 & 9.4 & 10.50 & 7.56 & 7.0 \\
\hline April & 23 & 26.2 & 26.8 & 25.0 & 8.9 & 8.9 & 8.3 & 14.28 & 10.08 & 5.0 \\
\hline May & 4 & 26.8 & - & 一 & 10.0 & - & - & 1.26 & - & - \\
\hline May & 9 & 25.7 & 26.2 & 23.2 & 12.8 & 12.8 & 12.2 & 5.04 & 7.56 & 5.0 \\
\hline May & 20 & 26.8 & 26.8 & 25.4 & 13.9 & - & 15.0 & 10.50 & 2.10 & 4.0 \\
\hline May & 27 & 26.6 & 26.9 & 25.8 & 11.1 & 10.0 & 11.7 & 15.12 & 19.74 & 4.0 \\
\hline June & 11 & 22.2 & 23.0 & 22.4 & 17.8 & 12.2 & 18.3 & 0.42 & 0.84 & 5.0 \\
\hline June & 17 & 19.2 & 20.3 & 12.6 & 20.0 & 20.0 & 20.6 & - & 0.84 & 3.0 \\
\hline July & 8 & 25.5 & 26.0 & - & 17.8 & 17.2 & - & 2.30 & - & 4.0 \\
\hline July & 23 & 21.2 & - & 23.9 & 18.9 & - & 20.6 & 0.84 & 0.84 & 4.0 \\
\hline July & 28 & 25.5 & 27.0 & 24.2 & - & - & 19.4 & 1.68 & 1.68 & 5.0 \\
\hline Sept. & 25 & 28.9 & 28.9 & - & 12.2 & 10.0 & - & 9.24 & 4.20 & 5.0 \\
\hline $\begin{array}{l}\text { October } \\
1970\end{array}$ & 24 & 29.1 & 31.1 & 28.0 & 10.0 & 10.0 & 10.6 & 15.54 & 24.36 & 5.0 \\
\hline January & 28 & 29.5 & 29.5 & 28.2 & 6.0 & 6.6 & 6.6 & & & 6.0 \\
\hline Feb. & 23 & 27.2 & 29.6 & 24.6 & 7.9 & 7.5 & 6.6 & & & 5.0 \\
\hline March & 11 & 28.9 & 29.5 & 27.0 & 7.1 & 7.4 & 7.2 & & & 3.0 \\
\hline March & 26 & 29.6 & 29.4 & 一 & 8.0 & 8.0 & - & & & 6.0 \\
\hline April & 3 & 27.8 & 27.8 & 28.9 & 8.5 & 8.8 & 8.9 & & & 5.0 \\
\hline April & 21 & 30.1 & 30.0 & 28.8 & 10.2 & 10.2 & 10.0 & & & 4.0 \\
\hline May & 4 & 29.3 & 30.0 & 27.8 & 12.0 & 9.0 & 12.2 & & & 5.0 \\
\hline June & 2 & 28.9 & 28.9 & 27.3 & 16.5 & 12.0 & 18.3 & & & 5.5 \\
\hline
\end{tabular}

experiments, the time prior to and including the experimental time, and the previous day (MONTHLY Radiation Summary 1970). On June 2, when radiation was highest, pigment concentrations were lowest. On April 3 and May 4 radiation was quite low and pigment concentrations high, and radiation was high on the previous days, particularly May 3.

Salinity and temperature measured at the surface and various depths are given in Table 8. The surface data are quite similar to measurements made on the same days at the Fisheries Research Board (FRB) Biological Station, Departure Bay (Hollister, personal communication), also cited in Table 8. The daily FRB data may therefore be considered as representative of surface conditions year-round at the project site. Changes in salinity and temperature with depth were slight during the period of rapid growth of Nereocystis luetkeana from March to May, with no more than a $3^{\circ} \mathrm{C}$ difference in temperature and 1\%0 difference in salinity. Greater extremes were encountered in June and July when most of the plants had reached the surface.

Nitrate determinations were made on fewer occasions and the data indicate that concentrations at the surface and at depth fluctuate in a similar manner (Table 8). 
Table 9

Total irradiation at various depths over kelp bed on four days at Departure Bay, B. C. Percent of total irradiation in the blue $(420 \mathrm{~nm}-490 \mathrm{~nm})$, green $(490 \mathrm{~nm}-580 \mathrm{~nm})$ and red $(650 \mathrm{~nm}$ to $729 \mathrm{~nm}$ ) is given and the ratio of red to far-red irradiation $(660 \mathrm{~nm} / 729 \mathrm{~nm})$ for May 4, with $K$ values (diffuse attenuation functions $[K]$ ) for the two wavelengths

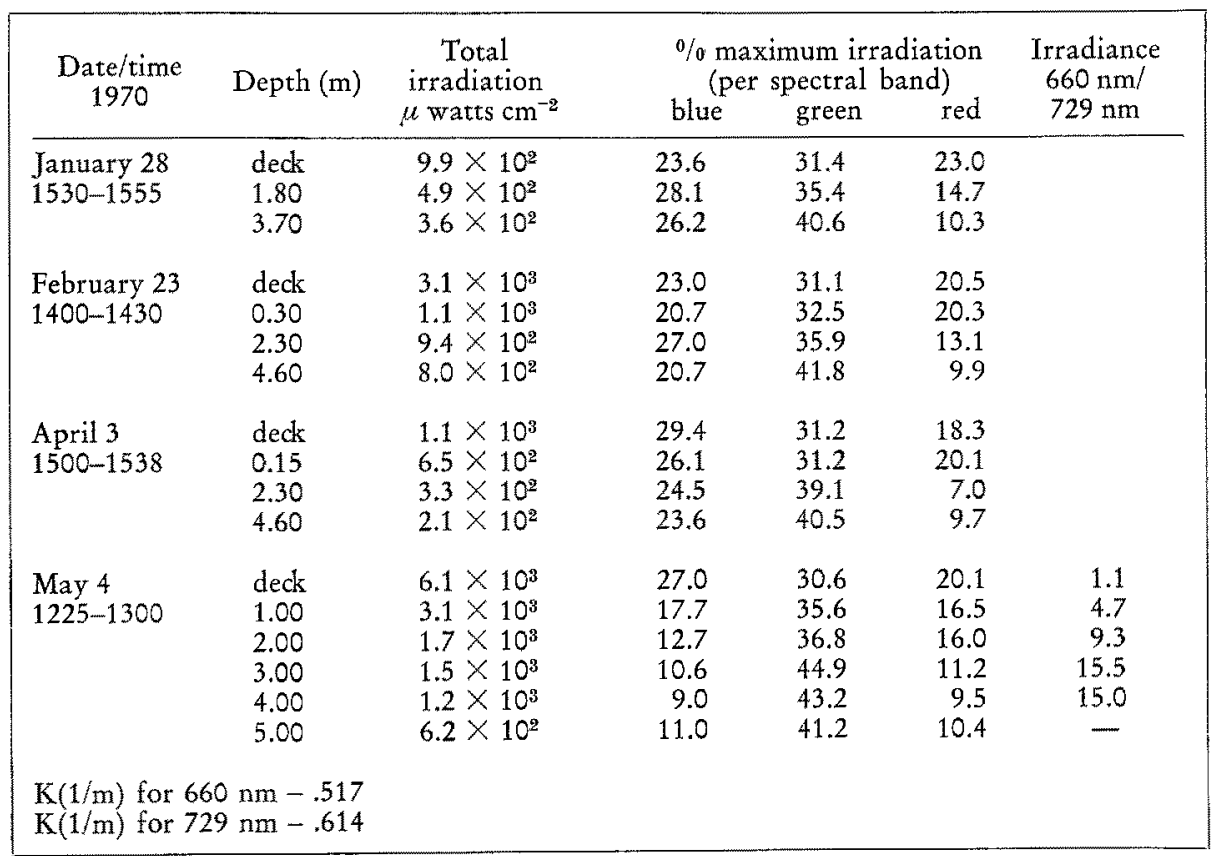

Irradiance measured at various depths and on deck, on four occasions, is presented in Table 10, together with the percentage of total irradiance in the blue, green and red wave bands. Irradiance at representative wavelengths are plotted against depth in Figure 3. The submarine measurements have been corrected for the immersion factor (SMrTH 1969) at each wavelength. The ratio of red to far-red irradiance $(660 \mathrm{~nm} /$ $729 \mathrm{~nm}$ ) calculated for one day, is also presented in Table 9, with diffuse attenuation values $(\mathrm{K})$ for the two wavelengths.

\section{DISCUSSION}

The results of the stipe elongation study in Departure Bay indicate that the distance from the surface govern rates of rapid stipe elongation. The transplants in this study, placed at $2 \mathrm{~m}$ below mean low tide, had an overall stipe elongation rate of approximately $1.6 \mathrm{~cm}$ per day, the same as the average rate calculated for intertidal Nereocystis luetkeana control sporophytes from the data of Nicholson (1970). The maximum rate of stipe elongation for control plants at $4 \mathrm{~m}$ below mean low tide was $7.8 \mathrm{~cm}$ per day, considerably less than the maximum rate of $12.7 \mathrm{~cm}$ per day calculated 
for Nereocystis luetkeana growing in deeper water $(5.5 \mathrm{~m}$ ) in California (ForEMAN 1970). At the time of measurement the California sporophytes were three times longer.

Age does not appear to be a major factor determining stipe elongation, assuming that plants of similar size, growing at the same depth prior to transplanting, are the same age. In this respect a large number of sporophytes cultured from spores in the

LOG SPECTRAL IRRADIANCE HWC-m ${ }^{-2} \mathrm{~nm}^{-1}$

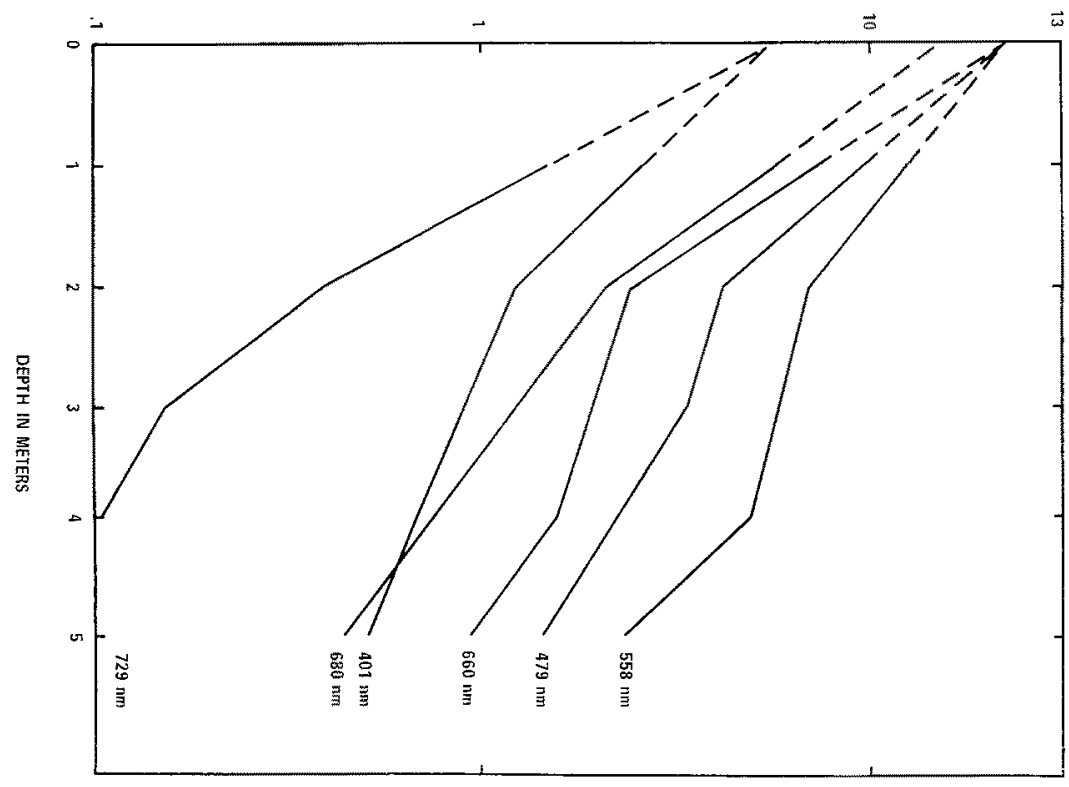

Fig. 3: Log spectral irradiance at 6 wavelengths, May 4, 1970, Departure Bay, B. C. Measurements were taken at 17 wavelengths from $1 \mathrm{~m}$ to $5 \mathrm{~m}$, between $1200 \mathrm{~h}$ and $1300 \mathrm{~h}$

laboratory and then placed in the sea would give more definitive results. Change in pressure also does not seem to contribute to stipe elongation, as the stipes of specimens tied to the bottom were quite similar in length at the final measurement to those placed nearer the surface.

From the environmental parameters measured, it appears that spectral irradiation would have the greatest effect on stipe elongation. It is not possible from the field studies to separate the effects of irradiation from spectral distribution. The influence of irradiation on sporophyte growth is most obvious in the initial stages. Recognizable sporophytes of Nereocystis luetkeana were first observed at $4 \mathrm{~m}$ and lesser depths in 
the coastal waters of British Columbia in early March, when low spring tides first occur in daylight hours (Canadian Tide and Current Charts 1971). The sporophytes began to reach the surface in May from depths of approximately $4 \mathrm{~m}$. VADAs (1972) found that in the nearby San Juan Islands of Washington (USA), Nereocystis luetkeana appeared at about the same time of year. In culture studies he observed that gametophytes and early sporophytes had relatively high saturating light intensity (200 ft. c.) compared to other Laminariales, and suggests this requirement relates to the time sporophyte grow th starts in the field (VADAS 1972).

The intensity for the saturation of photosynthesis in older sporophytes of Nereocystis luetkeana is not known. However, for other Laminariales a saturating intensity of $400 \mu \mathrm{gcal} \mathrm{cm}^{-2} \mathrm{sec}^{-1}$ was measured by LüNING (1971). Irradiation as high as this was measured between 2 and $3 \mathrm{~m}$ in early May, as the sporophytes were nearing the surface. In addition, Nereocystis luetkeana continues to increase its mass at a high rate, after rapid stipe elongation ceases (ForEMAN 1970). It would therefore seem that photosynthesis alone is not responsible for the pattern of stipe growth.

HuRd (1916) postulated that stipe elongation was favoured by the dim light of deeper water, and that higher intensities at the surface inhibited stipe elongation. However when sporophytes, both young and mature, were attached to the bottom, low irradiation did not produce the maximum elongation rates. It is noteworthy that the ratio of red to far-red irradiation $(660 \mathrm{~nm} / 729 \mathrm{~nm})$ decreases quickly towards the surface, in the depths where rapid elongation takes place. Considering the possibility that the stipe growth pattern of Nereocystis luetkeana may be a phytochrome-like response, the author attempted to extract such a pigment using the methods of TAYLOR \& BonNER (1967) who purified plytochrome from the green alga, Mcsotaenium and the liverwort, Spbaerocarpus. Typical optical density changes were recorded in crude extracts of blade meristem tissue of Nereocystis luetkeana and in whole tissue, after illumination with red and far-red wavelengths (Duncan 1971).

DRING (1971), using the data of JERLOV (1968) for type 7 coastal waters, calculated the ratio of red to far-red irradiation as quanta, and concluded that in many subtidal regions there would be sufficient irradiation in the red region to trigger a phytodhrome reaction. Irradiation in red regions of the spectrum will vary from place to place, depending on a number of factors, including the amount of chlorophyll in the water, as demonstrated by TYLER \& SMITH (1967) who measured spectral irradiance at $5 \mathrm{~nm}$ intervals from $350 \mathrm{~nm}$ to $750 \mathrm{~nm}$ in a variety of natural water types. The waters of the kelp beds in this study fit type 7 of JerLov's (1968) classification of coastal waters (see BURR \& DUNCAN 1972). For an alga such as Nereocystis luetkeana, the amount of irradiation available in the red part of the spectrum is enhanced by its upward growth, as well as by tidal movement.

The experiments to learn the effect of altered depth and irradiation on pigment concentrations in Nereocystis luetkeana indicated that a period of four hours, chosen as being less than a tidal period, was sufficient to cause a decrease in concentrations of chlorophylls a and $c$, but is not long enough for a measurable increase. Specimens collected from $4 \mathrm{~m}$ depth showed lower concentrations of chlorophylis after being placed close to the surface, but specimens collected from $2 \mathrm{~m}$ did not alter their chlorophyll concentrations when placed at $4 \mathrm{~m}$. YENTSCH \& SCAGEL (1958) obtained similar 
results in a diurnal study of pigments in a natural phytoplankton population consisting primarily of diatoms. Plankton from greater depths showed high fluctuations in pigment content from small changes in illumination, while the plankton in surface waters underwent only small changes in pigment concentrations through wide changes in light intensity. Chlorophyll c concentrations decreased when chlorophyll a increased and YENTSCH \& SCAGEL (1958) suggested chlorophyll $c$ may function as a precursor of chlorophyll a. In Nereocystis luetkeana chlorophyll $\mathrm{c}$ shifted in the same direction as chlorophyll $a$, and the quantities were somewhat too high and constant for a precursor.

Carotenoid concentrations did not alter during the experimental period of this study, but there was a significant difference in concentrations between deep $(4 \mathrm{~m})$ and shallow $(2 \mathrm{~m})$ specimens, when analyzed over the five testing days. Fucoxanthin, the major carotenoid in brown algae and diatoms has been demonstrated to transfer energy to chlorophyll a in diatoms (TANADA 1951, MANN \& MYers 1968) and its function is considered to provide more efficient photosynthesis in the blue-green wavebands of fucoxanthin absorption, present at the greater depths of kelp growth. However, Lubimenko \& Trchovskaja (1928), in an investigation of green, brown and red algae from depths down to $50 \mathrm{~m}$ in the Black Sea, found that total quantity of pigments determined an alga's capability to photosynthesize with irradiation equivalent to that found at $50 \mathrm{~m}$. In red and brown algae the accessory pigments replaced chlorophyll in varying proportions, with greater concentrations in the algae growing below $10 \mathrm{~m}$ than in the same species from more shallow depths. Lubimenko \& Tichovskaja (1928) concluded that the function of accessory pigments could not be attributed exclusively to the utilization of available irradiation for photosynthesis and suggest these pigments play a more complex role in the slower development of algae growing in the lower light intensities and lower temperatures of deep water.

There was no evidence from this investigation of consistently greater concentrations of fucoxanthin in specimens growing at $4 \mathrm{~m}$. In Nereocystis luetkeana fucoxanthin may be of greater significance in the development of gametophytes over the winter, and in early sporophytes at depths greater than $4 \mathrm{~m}$.

\section{SUMMARY}

1. Transplant studies of Nereocystis luetkeana indicate that the maximum rate of stipe elongation is a function of depth.

2. Salinity, temperature, nitrate concentrations and spectral irradiance were measured with depth and time, to learn which environmental factor or factors contributed to the pattern of stipe growth. Spectral irradiance showed the greatest and most consistent changes and is considered the principal factor affecting stipe elongation of Nereocystis luetkeana.

3. The depths at which stipes of Nereocystis luetkeana lengthened at a maximum rate corresponded to a decrease in the ratio of red to far-red wavelengths, suggesting the pattern of stipe growth may be a phytochrome-like response.

4. Photosynthetic pigments appear to respond to diurnal radiation with changes in concentration. Chlorophyll a and chlorophyll $\mathrm{c}$ in specimens collected at $4 \mathrm{~m}$ altered 
when the plants were kept at different constant depths for four hours. The chlorophylls of specimens from $2 \mathrm{~m}$ did not alter their concentrations. Carotenoids in Nereocystis luetkeana from neither $4 \mathrm{~m}$ nor $2 \mathrm{~m}$ changed in concentration in response to altered depths.

Acknowledgements. I wish to thank Dr. L. D. Druent for his valuable suggestions and comments during the course of this study, and Messrs. I. BritT, D. PACE and N. Stannton who provided expert SCUBA diving assistance.

\section{LITERATURE CITED}

Burr, A. H. \& Duncan, M. J., 1972. Portable spectroradiometer for underwater environments. Limnol. Oceanogr. 17, 466-475.

Canadian Tide and Currents Charts, 1971. (Ed. by: Can. Hydrographic Service, Marine Science Branch.)

DRING, M. J,, 1971. Light quality and the photomorphogenesis of algae in marine environments. In: Fourth European Marine Biology Symposium. Ed. by D. J. Crisp. Cambridge Univ. Press, Cambridge, 375-392.

Druent, L. D., 1970. The pattern of Laminariales distribution in the northeast Pacific. Phycologia 9, 237-247.

Duncan, M. J., 1971. Aspects of the pigment biology and ecology of Nereocystis luetkeana. Ph.D. Diss. Simon Fraser University, Burnaby, $100 \mathrm{pp}$.

Foreman, R. E., 1970. Physiology, ecology and development of the brown alga Nereocystis luetkeana (Mertens) P. \& R. Ph.D. Diss. Univ. Calif., Berkeley, Calif., 114 pp.

Frye, T. C., 1930. Splitting of the leaf of Nereocystis. Publs Puget Sound mar. biol. Stn 7 , 413-416.

- 1906. Nereocystis luetkeana. Bot. Gaz. 42, 143-146.

Hartge, L. A., 1928. Nereocystis. Publs Puget Sound mar. biol. Stn 6, 207-237.

Hurn, A. M., 1916. Factors influencing the growth and distribution of Nereocystis luetkeana. Publs Puget Sound mar. biol. Stn 1, 185-197.

Jerlov, N., 1968. Optical oceanography. Elsevier, New York, $194 \mathrm{pp}$.

Lubmenko, V. \& Tichovskaja, Z., 1928. Recherches sur la photosynthèse et l'adaptation chromatique chez les algues marines. L'Academie des Sciences de l'URSS.

LüNING, K., 1971. Seasonal growth of Laminaria byperborea under recorded underwater light conditions near Helgoland. In: Fourth European Marine Biology Symposium. Ed. by D. J. Crisp. Cambridge Univ. Press, Cambridge, 347-361.

MacMrltan, C., 1899. Observations on Nereocystis. Bull. Torrey bot. Club 26, 273-296.

ManN, J. E. \& Myers, J., 1968. On pigment growth and photosynthesis of Pbaeodactylum tricornutum. J. Phycol. 4, 349-355.

Monthly radiation summary, 1970. (Ed. by: Dept. Transport, Meteorol. Branch, Can.)

Nicholson, N., 1970. Field studies on the giant kelp Nereocystis luetkeana. J. Phycol. 6, $177-182$.

SeEly, G. R., Duncan, M. J. \& VIDAver, W. E., 1972. Preparative and analytical extraction. of pigments from brown algae with dimethyl sulfoxide. Mar. Biol. 12, 184-188.

Smiтн, R. C., 1969. An underwater spectral irradiation collector. J. mar. Res. 27, 341-351.

TANADA, T., 1951. The photosynthetic efficiency of carotenoid pigments in Navicula minima. Am. J. Bot. 38, 276-283.

TAYlor, A. O. \& BONNER, B. A., 1967. Isolation of phytochrome from the algae Maesotaenium and liverwort Sphaerocarpos. Pl. Physiol, 42, 762-766.

TyLeR, J. E. \& SMTTH, R. C., 1967. Spectroradiometric characteristics of natural light under water. J. opt. Soc. Am. 57, 595-601. 
VADAS, R. L., 1972. Ecological implications of culture studies on Nereocystis luetkeana. J. Phycol. 8, 196-203.

Wood, E. D., Armstrong, F. A. J. \& Richards, F. W., 1967. Determination of nitrate in seawater by cadmium-copper reduction to nitrite. J. mar. biol. Ass. U. K. 24, 23-31.

YeNTSCH, C. S. \& SCAGEL, R. F., 1958. Diurnal study of phytoplankton pigments. J. mar. Res. 17, 567-583.

Author's address: Dr. MARY Jo Duncan

Biologische Anstalt Helgoland (Meeresstation)

2192 Helgoland

Federal Republic of Germany 